\title{
Locally Advanced Colorectal Carcinoma
}

National Cancer Institute

\section{Source}

National Cancer Institute. Locally Advanced Colorectal Carcinoma. NCI Thesaurus. Code C162766.

A colorectal carcinoma that has spread from its original site of growth to nearby tissues or lymph nodes. 